\title{
Research of Emergency Modes of Wind Power Plants Using Computer Simulation
}

\author{
Mohamed Zaidan Qawaqzeh ${ }^{1, *(1)}$, Oleksandr Miroshnyk ${ }^{2}$ (), Taras Shchur ${ }^{3}$, Robert Kasner ${ }^{4}$, Adam Idzikowski $^{5}$, \\ Weronika Kruszelnicka ${ }^{4}$, Andrzej Tomporowski ${ }^{4, * \mathbb{D}}$, Patrycja Bałdowska-Witos ${ }^{4}{ }^{\mathbb{D}}$, Józef Flizikowski ${ }^{4}$, \\ Marcin Zawada ${ }^{5}\left(\mathbb{D}\right.$ and Krzysztof Doerffer ${ }^{6}[0$
}

check for

updates

Citation: Qawaqzeh, M.Z.;

Miroshnyk, O.; Shchur, T.; Kasner, R.;

Idzikowski, A.; Kruszelnicka, W.;

Tomporowski, A.; Bałdowska-Witos,

P.; Flizikowski, J.; Zawada, M.; et al.

Research of Emergency Modes of

Wind Power Plants Using Computer

Simulation. Energies 2021, 14, 4780.

https://doi.org/10.3390/en14164780

Academic Editors: Andrzej L. Wasiak and Frede Blaabjerg

Received: 27 May 2021

Accepted: 3 August 2021

Published: 6 August 2021

Publisher's Note: MDPI stays neutral with regard to jurisdictional claims in published maps and institutional affiliations.

Copyright: (c) 2021 by the authors. Licensee MDPI, Basel, Switzerland This article is an open access article distributed under the terms and conditions of the Creative Commons Attribution (CC BY) license (https:/ / creativecommons.org/licenses/by/ $4.0 /)$.
1 Ma'an University College, Al-Balqa' Applied University, P.O. Box 194, Ma'an 19117, Jordan

2 Department of Electricity Supply and Energy Management, Kharkiv Petro Vasylenko National Technical University of Agriculture, Alchevskih Street 44, 61002 Kharkiv, Ukraine; omiroshnyk@ukr.net

3 Department of Cars and Tractors, Faculty of Mechanics and Energy, Lviv National Agrarian University, 30831 Dublyany, Ukraine; shchurtg@gmail.com

4 Department of Machines and Technical Systems, University of Science and Technology in Bydgoszcz, Al. Prof. S. Kaliskiego 7, 85-796 Bydgoszcz, Poland; robert.kasner@utp.edu.pl (R.K.); weronika.kruszelnicka@utp.edu.pl (W.K.); patrycja.baldowska-witos@utp.edu.pl (P.B.-W.); fliz@utp.edu.pl (J.F.)

5 Faculty of Management, Czestochowa University of Technology, ul. Armii Krajowej 19 B, 42-200 Częstochowa, Poland; adam.idzikowski@wz.pcz.pl (A.I.); marcin.zawada@pcz.pl (M.Z.)

6 Department of Manufacturing and Production Engineering, Faculty of Mechanical Engineering and Ship Technology, Gdańsk University of Technology, ul. Gabriela Narutowicza 11/12, 80-233 Gdańsk, Poland; krzysztof.doerffer@pg.edu.pl

* Correspondence: qawaqzeh@bau.edu.jo (M.Z.Q.); a.tomporowski@utp.edu.pl (A.T.)

\begin{abstract}
The aim of this study is to investigate changes in the wind power plant energy production parameters under the conditions of sudden wind changes and voltage drop. To achieve these goals, a simulation of operation of wind power plants was performed. Twelve wind turbines with variable rotational speed equipped with a Fuhrländer FL 2500/104 asynchronous double-fed induction generator (DFIG) were used, each with an installed capacity of $2.5 \mathrm{MW}$. A general scheme of a wind power plant has been developed using a modular-trunk power distribution scheme. The system consists of wind power modules and a central substation, which allows total power to be supplied to the power system at a voltage of $35 \mathrm{kV}$. The central substation uses two high voltage switchgears. Four modules were used, each of them consisting of three wind turbines, with a power of $7.5 \mathrm{MW}$. The simulation of the wind turbines was performed in the MATLAB ${ }^{\circledR}$ Simulink ${ }^{\circledR}$ software environment. The mode of response of the turbines to a change in wind speed, a voltage drop in the $35 \mathrm{kV}$ voltage system, and a one-phase short circuit to the ground in the system of $10.5 \mathrm{kV}$ voltage was explored. The results show that a sudden voltage drop and the appearance of short circuits influence the wind power plant (WPP) operation in a different way independent of regulation mode. The power generation from WPP will be limited when voltage drop occurred for both AC and Voltage regulation mode and during short circuits while WPP is set on AC regulation mode.
\end{abstract}

Keywords: wind power plant; wind turbines; one-phase short circuit; voltage drop; computer simulation

\section{Introduction}

Wind power is developing at a rapid pace all over the world. According to the World Wind Energy Association, by the end of 2020, the installed capacity of all wind power plants all over the world reached 744 GW [1]. Over the past twenty years, this area has evolved from an exotic phenomenon to a rapidly developing industry, where more efficient and reliable technologies have been implemented, and the costs have almost halved in the last ten years, which has enabled commercial production. Modern wind turbines are 
capable of producing several times more electricity than 20 years ago, and the cost of equipment per unit of output $(\mathrm{kW} / \mathrm{h})$ has more than doubled over the years. Moreover, evolution of wind energy production into an independent industry has had a positive effect on the economic development of modern society. The Wind Energy Council has estimated the employment in the wind energy sector to be around 350,000.

Ukraine has numerous wind energy resources and, due to its natural and climatic characteristics, can become one of the leading countries in wind energy utilization [2-5]. The total installed capacity is about $1.3 \mathrm{GW}[6,7]$. Ukraine is able to effectively use wind energy in some areas with an average annual wind speed of more than $5 \mathrm{~m} / \mathrm{s}$. This speed is sufficient for the operation of wind turbines.

According to Ukraine's energy strategy, by 2035, the share of electricity produced from renewable energy sources should account for $25 \%$ of the country's total production. According to commitments made to the European Energy Community, Ukraine will have increased the share of renewable energy sources (RES) in the country's energy balance by $11 \%$ (data refers to 2020 ) [8-11].

In order to ensure the independence of Ukraine from commodity imports, and thanks to the current green tariff law, generation of electricity from renewable sources is important and necessary for the development of the modern electricity sector, and to provide Ukraine with the most advanced, innovative technologies [12-15].

Therefore, the problems addressed in this study concerning the operation of wind power plants in the electricity grid are very significant. The most efficient operation of wind farms requires knowledge about the performance of a wind farm and the turbine behavior on the grid, especially its power generation and voltage levels under different wind conditions. Factors necessary for the study of wind farm design are: selection of the power plant construction site, development of the power output scheme, selection of the generator type and turbines, and the study of the wind farm impact on emergency modes in the electrical network [12,13,16-23]. As mentioned in [17], the configuration of a wind farm location largely affects the wind farm power output. Configuration of the turbines in a line and orientation perpendicular to the free-stream of wind provides maximum performance. Attempts to optimize a wind farm arrangement were also made using genetic algorithms [18-20]. It was also found that, thanks to the use of energy storage systems, about $20 \%$ of total curtailment can be avoided [16].

Investigating the influence of wind farms on power systems and predicting the quantity and quality parameters of the produced energy fed into the grid is possible by the modeling and simulation of a wind farm operation, e.g., in MATLAB ${ }^{\circledR}$ Simulink ${ }^{\circledR}$ (The MathWorks, Natick, MA, USA) software or Python ${ }^{\mathrm{TM}}$ (Python Software Foundation, Wilmington, DE, USA). Several studies are devoted to computer simulation of wind turbines. Some papers investigate dynamic responses of small wind turbines to wind speed changes [24,25]. In study [26], a VAR compensator is proposed to control the parameters of wind turbines (voltage, power). A simulation was performed in MATLAB ${ }^{\circledR}$ software (The MathWorks, Natick, MA, USA), which showed that the use of a VAR compensator with a three-phase squirrel-cage induction generator gave good results and fast recovery from dynamic disturbances. Saheb-Koussa et al. [27] developed a model for wind turbines with fixed speed generators and using $M A T L A B^{\circledR}$ simulation proved that their model allowed the prediction of dynamic responses during wind turbine operation. A voltage adjustment model for variable wind speed was also introduced [28]. Jansuya and Kumsuwan [29] proposed a simulator for a fixed pitch angle wind turbine and showed that it could display mechanical power and torque suitable for variable wind speed conditions. Only a few studies deal with modeling of wind farm characteristics because of the complexity of this task [30,31]. Although the subject of dynamic response has already been described in the literature, there is still a lack of information about how wind farms respond to sudden changes in wind and drops in voltage. In this study, some performance characteristics of wind farms under these conditions are presented. 
The aim of this paper is to investigate changes in the wind power plant energy production parameters under the conditions of sudden wind changes and voltage drop. To achieve these goals, a simulation of the operation of three wind power plants with a rated power of $7.5 \mathrm{~kW}$, supplying one substation, and being part of a $10 \mathrm{MW}$ wind farm, was performed in MATLAB ${ }^{\circledR}$ Simulink ${ }^{\circledR}$.

\section{Materials and Methods}

Modern wind energy turbines (WET), which use power electronics (inverters) to connect to the electric grid and automatically adjust the operation mode of WET, unlike the first directly connected to the electrical grid WET built in Ukraine, are able to provide the grid with auxiliary services [32-34].

The necessity of analyzing power system operation modes while providing WPP auxiliary services requires adequate modeling of WET in calculations of electrical modes to determine the level of a power system's static stability from design organizations and the operators of backbone and distribution networks [35].

We performed simulations of real wind power plant operation modes. For this purpose, we selected the installed capacity of the designed wind power plant to be $30 \mathrm{MW}$. It was also decided to use 12 wind-driven Fuhrländer FL 2500 installations of German production, with a rotor diameter equal to $104 \mathrm{~m}$. The capacity of one wind turbine was 2.5 MW, and an asynchronous generator based on a dual power machine was used. The stator winding is connected directly to the $50 \mathrm{~Hz}$ network, and the rotor is connected to a variable frequency via an AC to DC converter (PWM based on IGBT transistors) (Figure 1). Asynchronous generator technology maximizes wind power for low wind speeds by optimizing turbine speed while minimizing mechanical loads on the turbine during wind gusts. The optimum turbine speed giving maximum mechanical energy for a given wind speed is proportional to the wind speed.

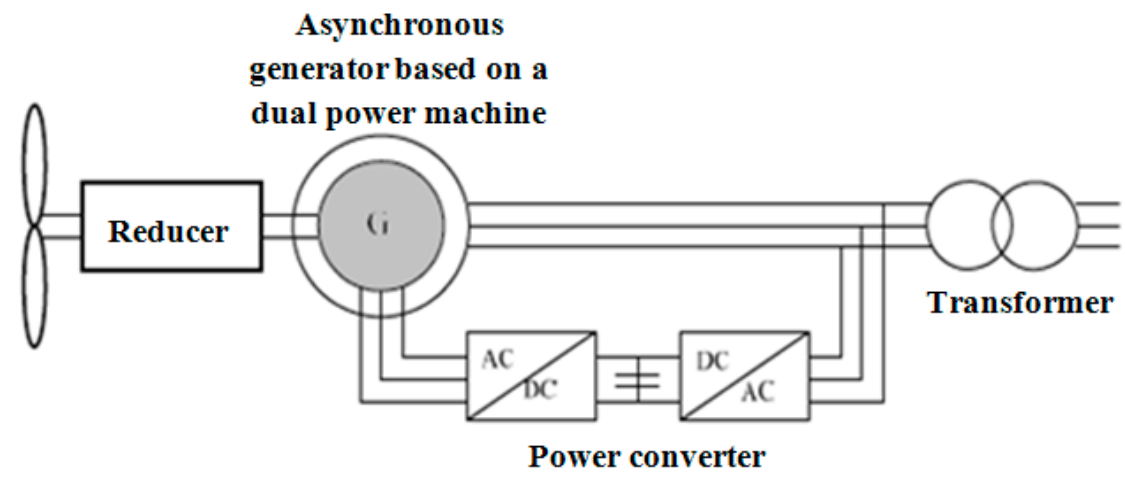

Figure 1. WET with asynchronous generator based on a dual power machine.

Figure 2 presents the power curve of a Fuhrländer FL 2500/104 wind turbine. At a wind speed below $10 \mathrm{~m} / \mathrm{s}$, the rotor operates at a sub-synchronous speed. At high wind speeds, it works at hyper-synchronous speeds. Another advantage of the asynchronous dual power generator technology is the ability of power electronic converters to generate or absorb reactive power, which eliminates the need to install capacitor batteries, as in the case of short circuit rotor asynchronous generators [36,37].

The wind farm system consists of wind power modules and a central substation, which allows the total power to be supplied to the power system at a voltage of $35 \mathrm{kV}$. The central substation uses 2 high voltage switchgears. When developing wind power modules, it was decided to use 4 modules, each of them consisting of 3 wind turbines; the power of 1 module was 7.5 MW. A 7.5 MW wind farm consisting of three wind turbines of $2.5 \mathrm{MW}$, connected to a $10.5 \mathrm{kV}$ distribution system exporting electricity to the $35 \mathrm{kV}$ grid. An installation with a voltage of $2300 \mathrm{~V}$, a power of $1.01 \mathrm{MVA}$, consisting of an engine load (asynchronous motor capacity of $1 \mathrm{MW}$ ) and a resistive load of $10 \mathrm{~kW}$, is connected to the buswork $10.5 \mathrm{~kW}$. Both the wind turbines and the engine load have a system to control the 
voltage, current, and rotation speed of the rotor. The DC link generator voltage of the wind electric installation is also monitored. The general wind farm scheme is shown in Figure 3.

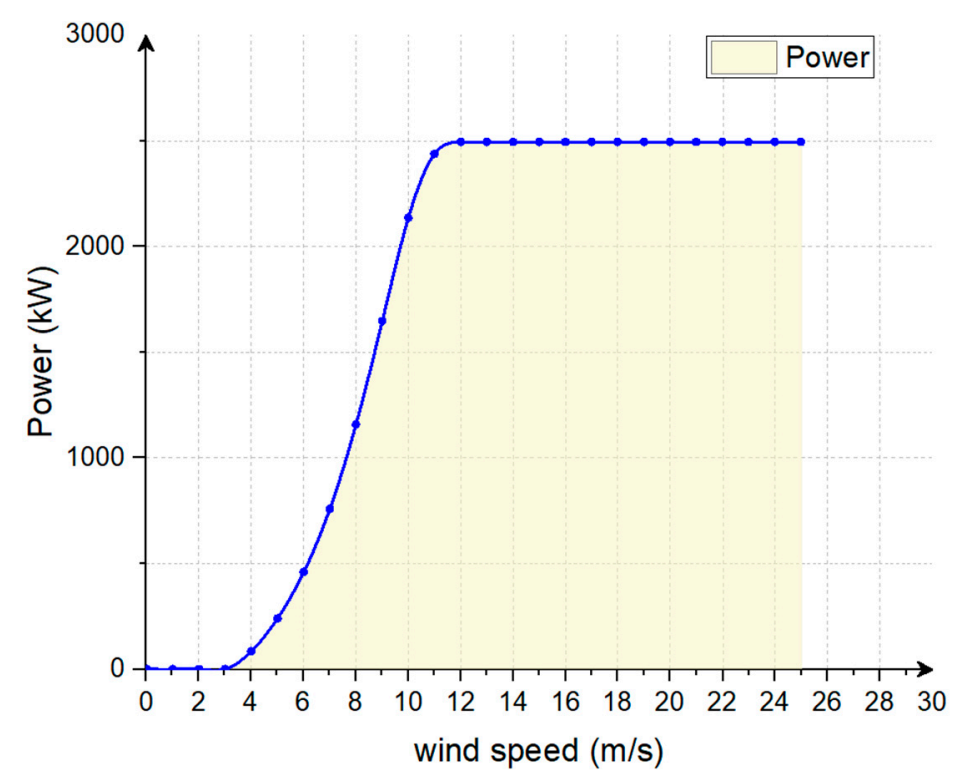

Figure 2. Power curve of a Fuhrländer FL 2500/104 wind turbine. Own work based on the [38].

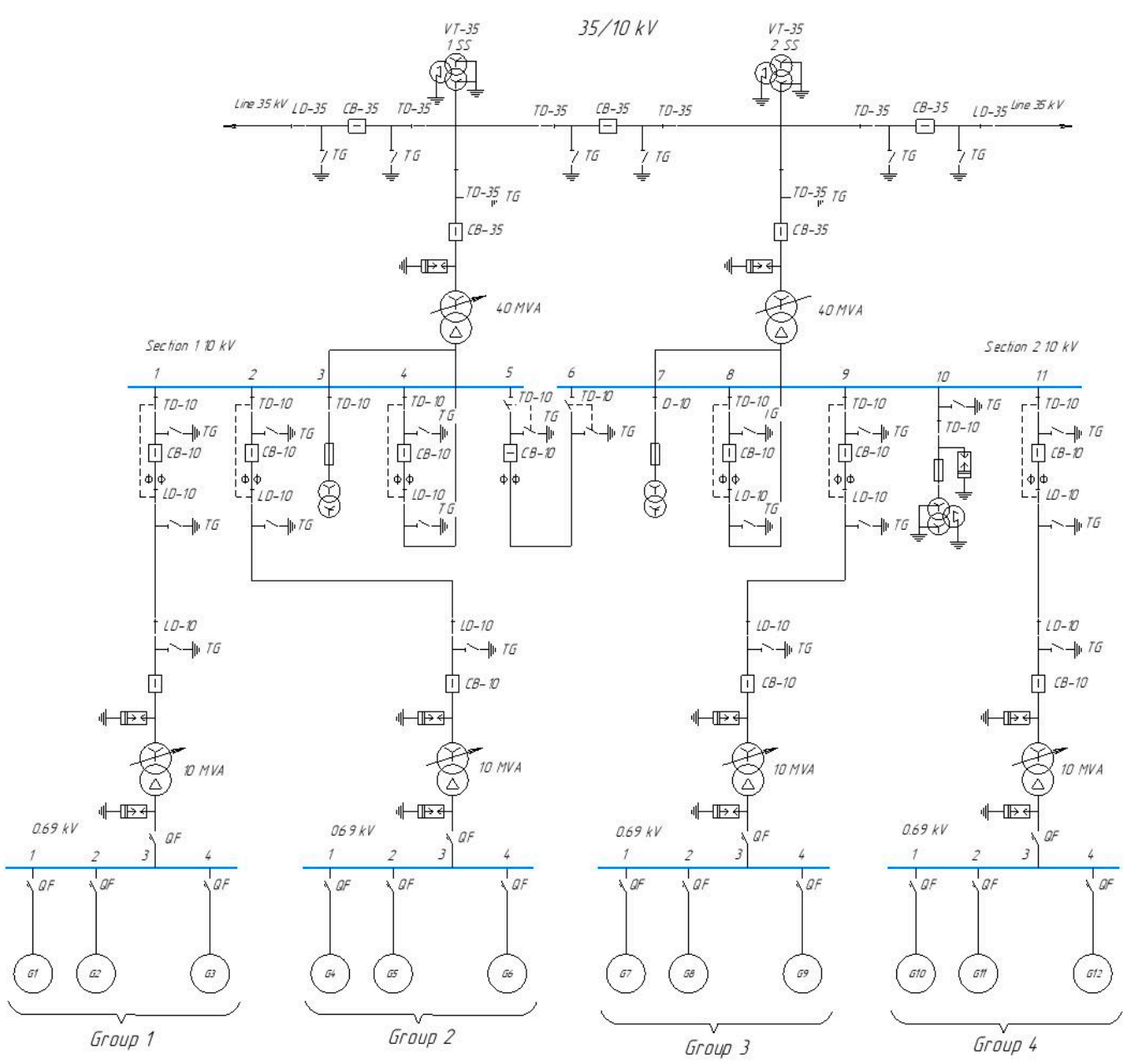

Figure 3. General wind farm scheme. 
The 7.5 MW wind farm model developed in MATLAB ${ }^{\circledR}$ Simulink $^{\circledR}$ is shown in Figure 4. A general scheme of the wind power plant was developed using a modular-trunk power distribution scheme.

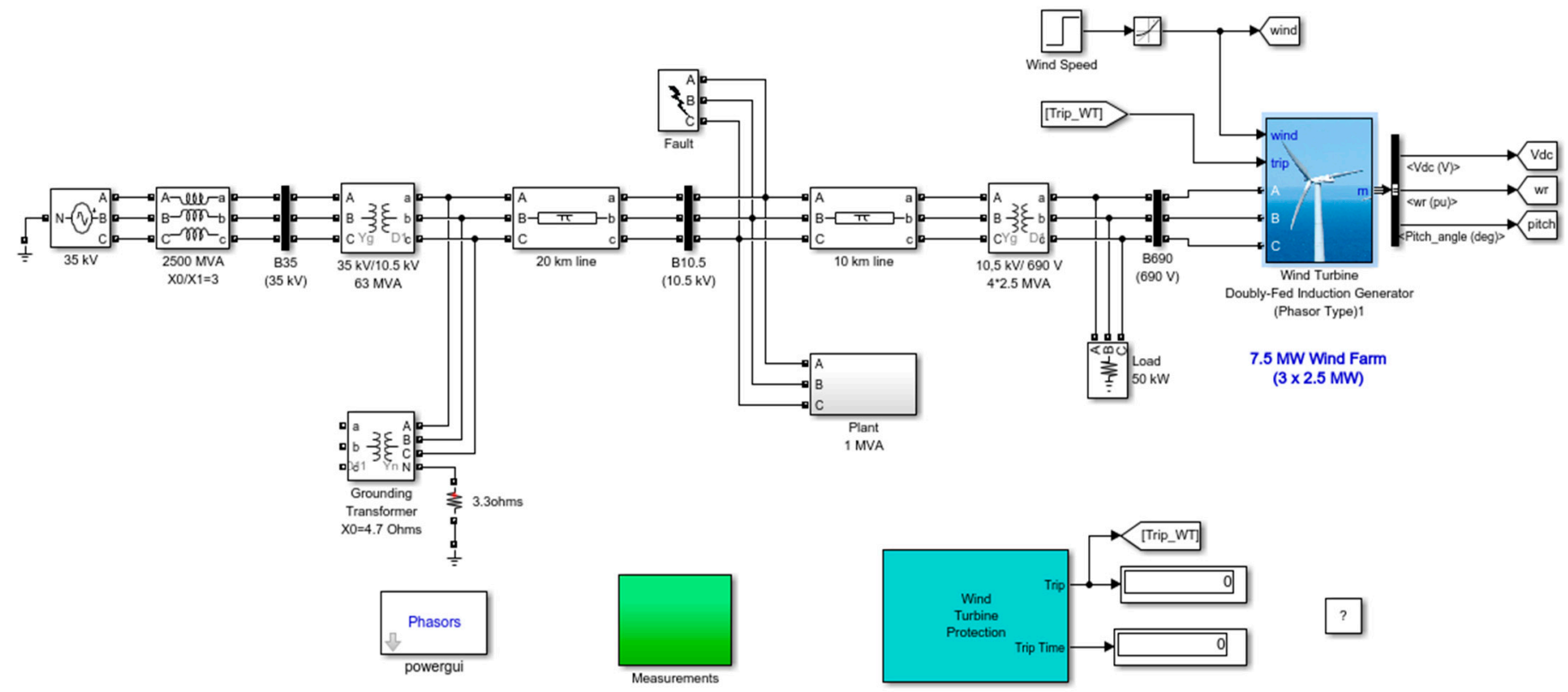

Figure 4. Model of a wind farm in the simulation environment MATLAB ${ }^{\circledR}$ Simulink $^{\circledR}$.

The wind turbine model is a vector model that enables long-term stability studies. In this example, the system is observed for $50 \mathrm{~s}$.

A wind farm consisting of 3 wind turbines is modelled by 1 wind turbine unit by multiplying the following parameters by 3 , as shown below:

1. Nominal mechanical power of the wind turbine: $3 \times 2.5 \mathrm{MW}$ indicated in the turbine data menu.

2. Rated power of the generator: $3 \times 2.5 / 0.9 \mathrm{MVA}(3 \times 2.5 \mathrm{MW})$ specified in the generator data menu.

In this study, we investigate the wind farm behavior for different cases:

- Wind farm operation in Voltage regulation and AC regulation mode assuming a sudden wind speed change-initially, wind speed is set to $8 \mathrm{~m} / \mathrm{s}$; then, at $\mathrm{t}=5 \mathrm{~s}$, wind speed suddenly increases to $14 \mathrm{~m} / \mathrm{s}$;

- Wind farm operation in Voltage regulation and AC adjustment mode assumes a sudden voltage drop-wind speed is constant and equal to $8 \mathrm{~m} / \mathrm{s}$, simulation time $\mathrm{t}=50 \mathrm{~s}$;

- Wind farm operation in a single-phase short circuit on earth in a system of $10.5 \mathrm{kV}$. We assumed the short circuit time $t=5 \mathrm{~s}$ and its duration $5+9 / 60 \mathrm{~s}$. Initially, wind speed is set to $8 \mathrm{~m} / \mathrm{s}$, then at $\mathrm{t}=5 \mathrm{~s}$ wind speed suddenly increases to $14 \mathrm{~m} / \mathrm{s}$.

\section{Research Results}

\subsection{Simulation of Wind Farm Operation under Conditions of Sudden Wind Speed Change}

We performed a simulation of the wind speed change. Initially, the wind speed was set to $8 \mathrm{~m} / \mathrm{s}$; then, at $\mathrm{t}=5 \mathrm{~s}$, wind speed suddenly increased to $14 \mathrm{~m} / \mathrm{s}$. At the start of the simulation, an oscilloscope monitored the voltage, current, active and reactive power, DC bus voltage, and turbine speed. The results of the study "Voltage regulation" operation mode are shown in Figure 5. At $t=5 \mathrm{~s}$, the active power starts to increase gradually (together with the speed of the turbines), reaching its nominal value of $7.5 \mathrm{MW}$ after about $18 \mathrm{~s}$. During this time, the speed of the turbines will increase from 0.8 units to 1.21 units. Initially, the turbine blade inclination angle is zero, and the operating point of the turbine 
follows the red curve of the turbine power characteristics to point $\mathrm{D}$. Then, the angle of inclination is increased from 0 to 0.76 degrees to limit the mechanical power. Reactive power is adjustable to maintain a voltage of 1 unit. At rated power, the wind turbine absorbs 0.6 MVar $(\mathrm{Q}=-0.6$ MVar generated) to maintain a voltage of 1 unit.
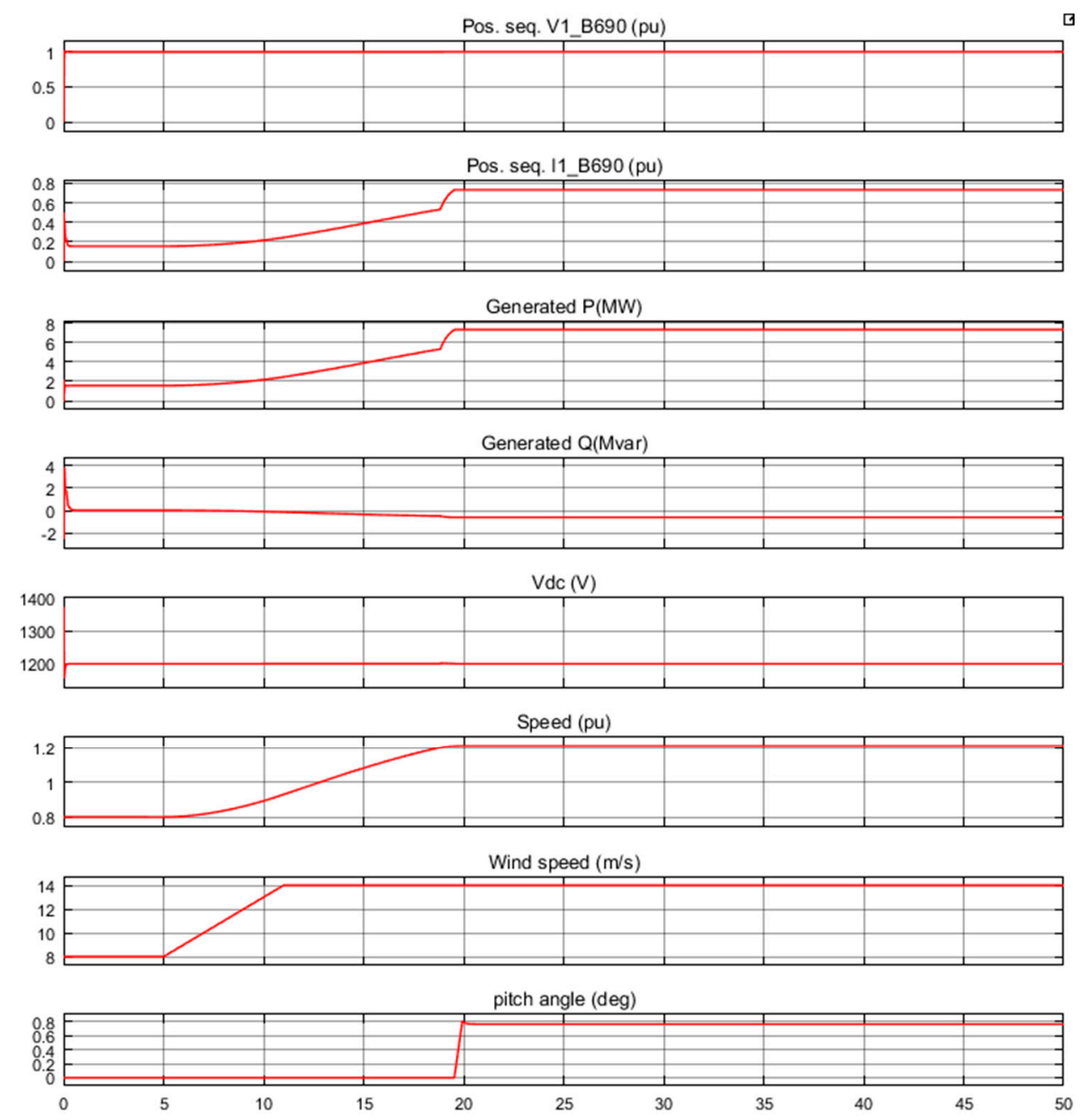

Figure 5. Characteristics of the wind farm with wind change from $8 \mathrm{~m} / \mathrm{s}$ to $14 \mathrm{~m} / \mathrm{s}$ in "Voltage regulation" mode.

If one changes the mode to "AC" when "Qref Generating Reactive Power" is set to zero, one can see that the voltage rises to 1.0185 units when the wind turbine generates its rated power at a single power factor. The results of the study of wind turbine operation under "AC regulation" mode are shown in Figures 6 and 7, respectively. 
Pos. seq. V1_B690(pu)

노

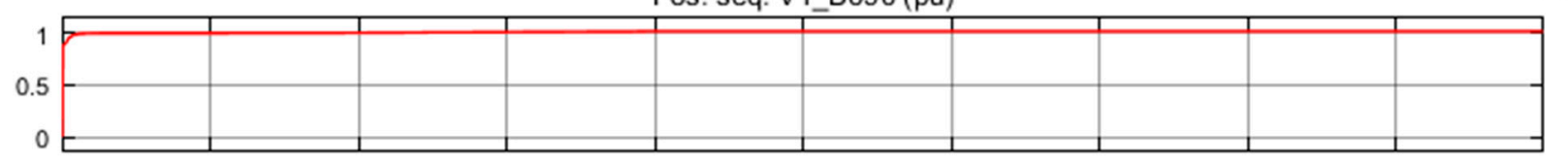

Pos. seq. I1_B690 (pu)
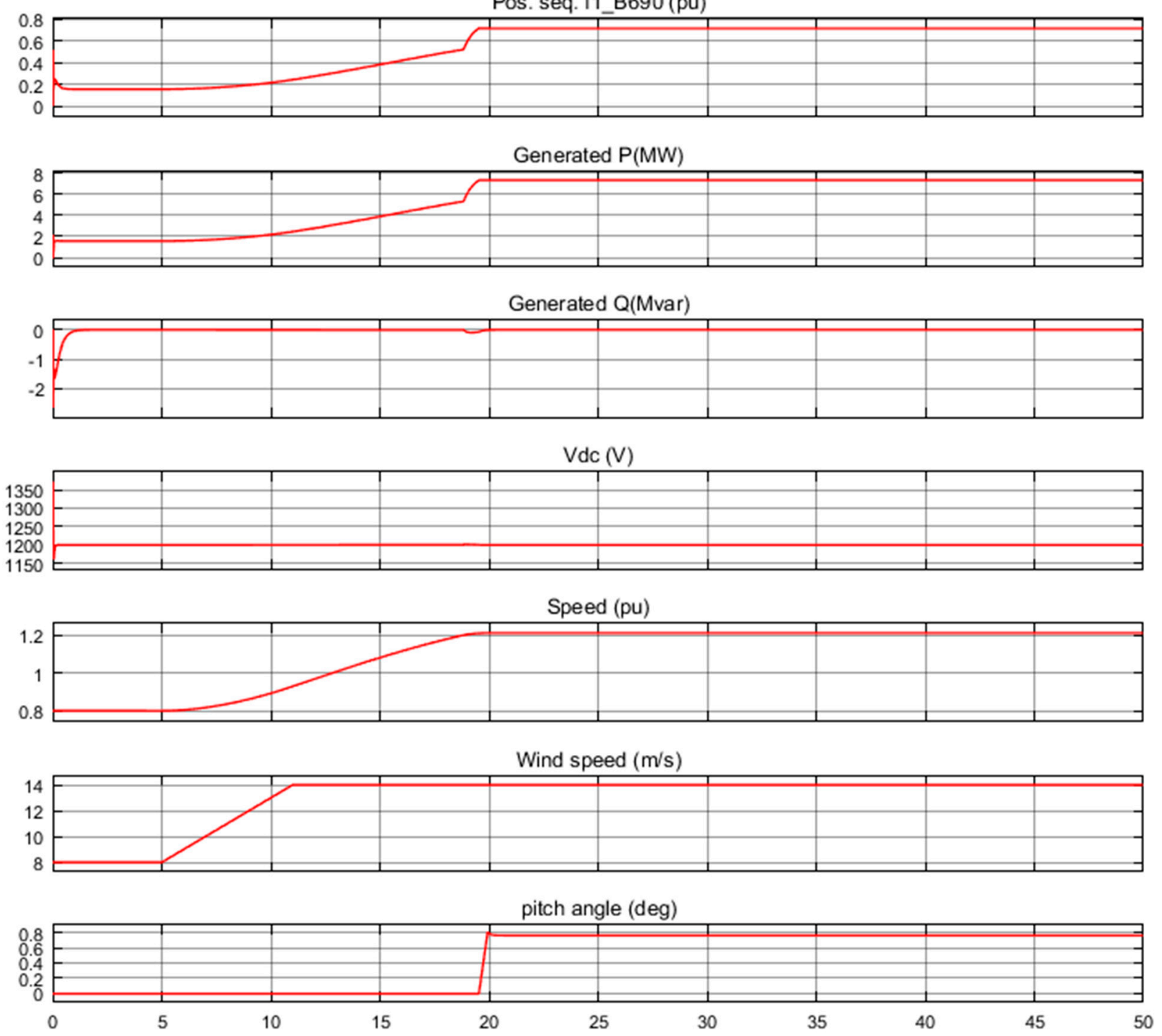

Figure 6. Characteristics of wind farm operation with wind change from $8 \mathrm{~m} / \mathrm{s}$ to $14 \mathrm{~m} / \mathrm{s}$ in "AC regulation" mode.

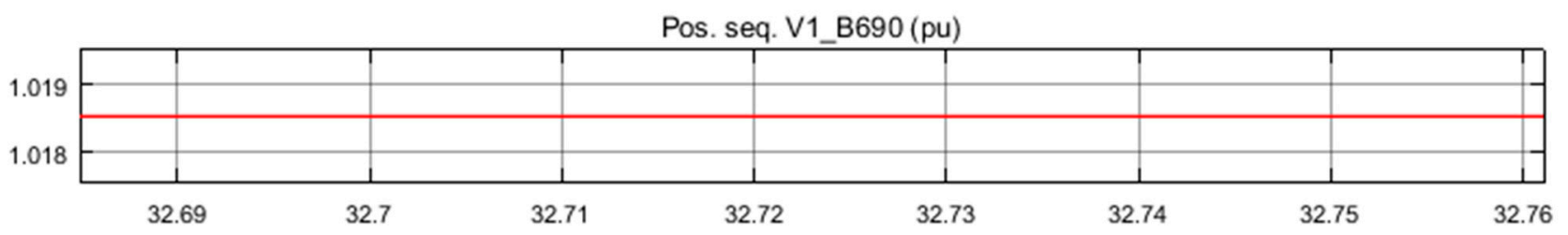

Figure 7. The value of the output voltage of the wind farm in the "AC regulation" mode of operation.

\subsection{Simulation of Wind Farm Operation under Conditions of Sudden Voltage Drop}

We then performed a simulation of the voltage drop in the system with a voltage of $35 \mathrm{kV}$. For a simulation of this mode, air speed was assumed to be constant throughout the simulation process $\mathrm{t}=50 \mathrm{~s}$, and equal to $8 \mathrm{~m} / \mathrm{s}$. 
The first mode in which the simulation was conducted was "AC adjustment" operation mode when "Generating reactive power $\mathrm{Q}_{\text {ref }}$ " was zero. The simulation results are shown in Figure 8, and the electric motor voltage when the voltage drops are shown in Figure 9.
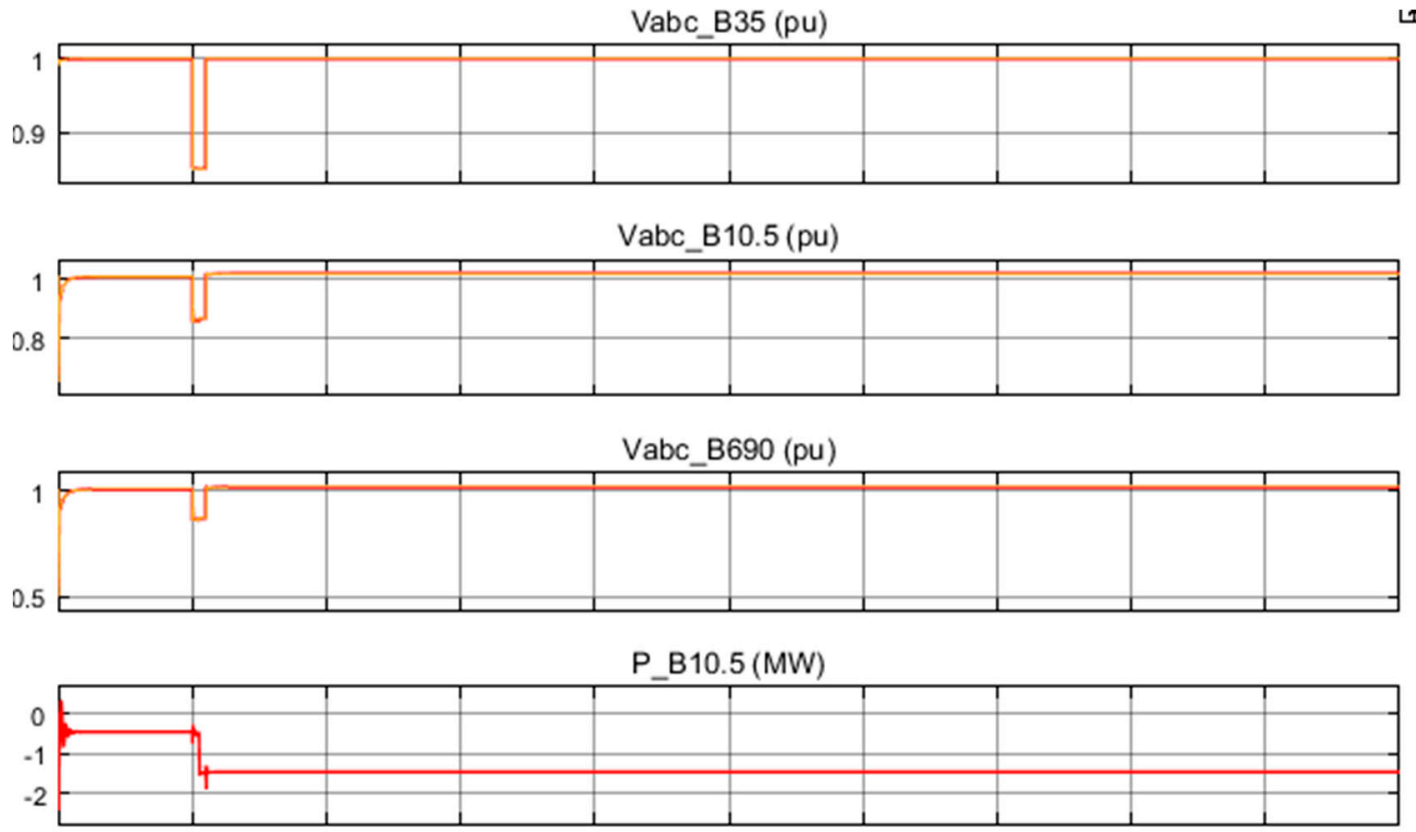

Q_B10.5 (Mvar)
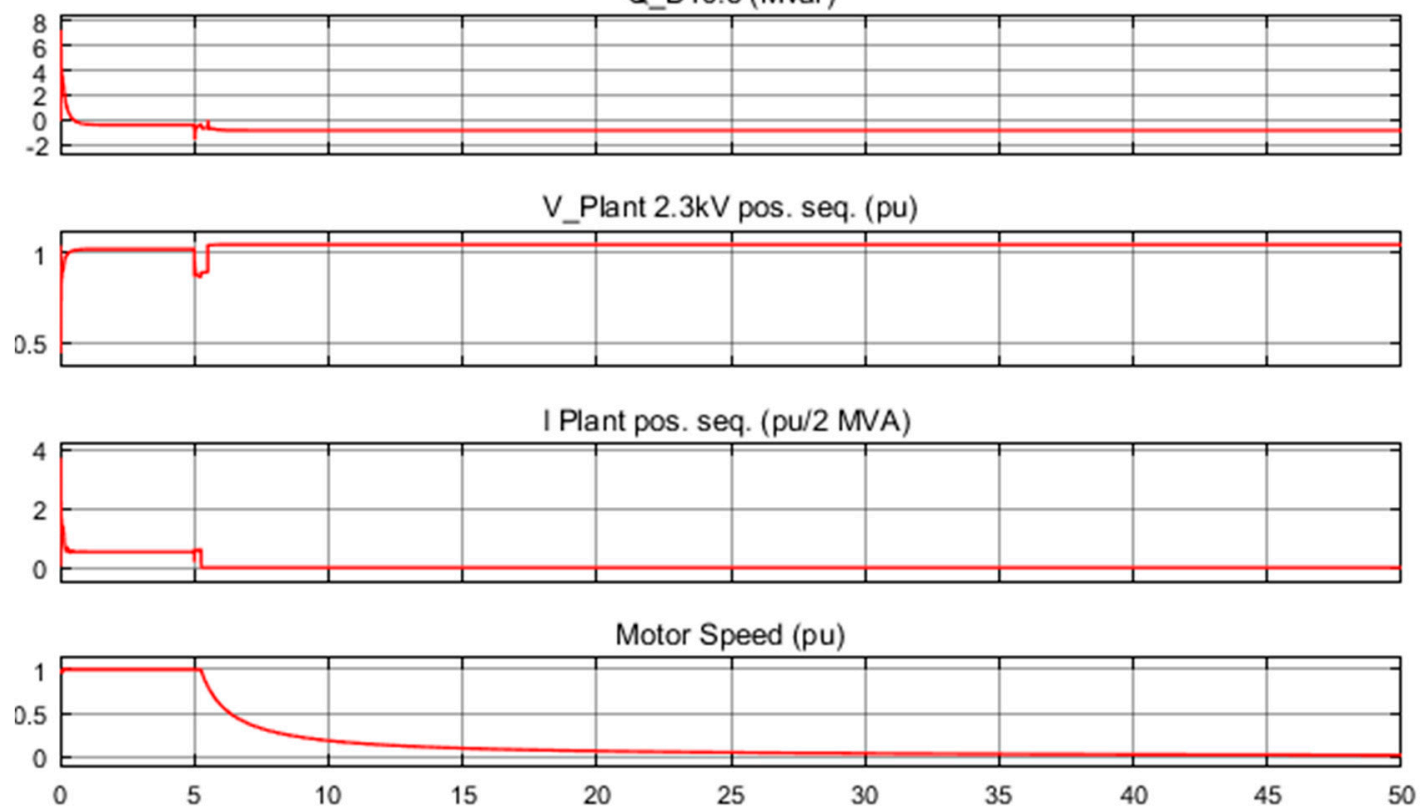

Figure 8. Characteristics of the motor response with a voltage drop in the $35 \mathrm{kV}$ system in the WPP "AC adjustment" operation mode.

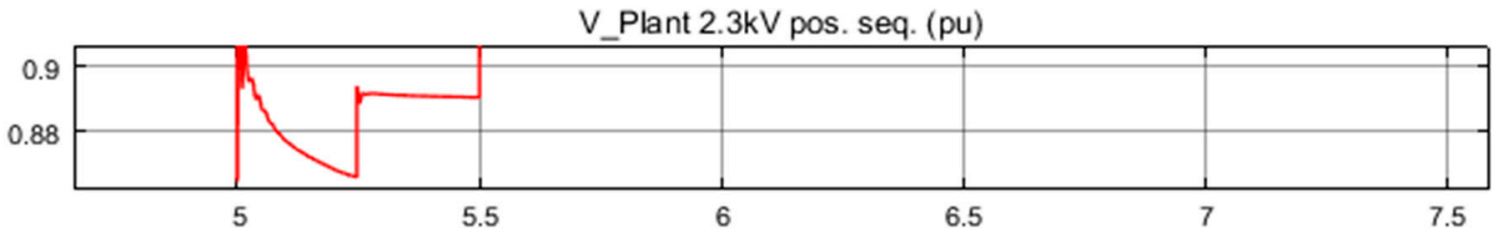

Figure 9. Electric motor voltage with a voltage drop in the $35 \mathrm{kV}$ system for WPP "AC adjustment" operation mode. 
The characteristics of the wind power station operation for a voltage drop in the system of $35 \mathrm{kV}$ for the WWP operation mode "AC adjustment" are shown in Figure 10.
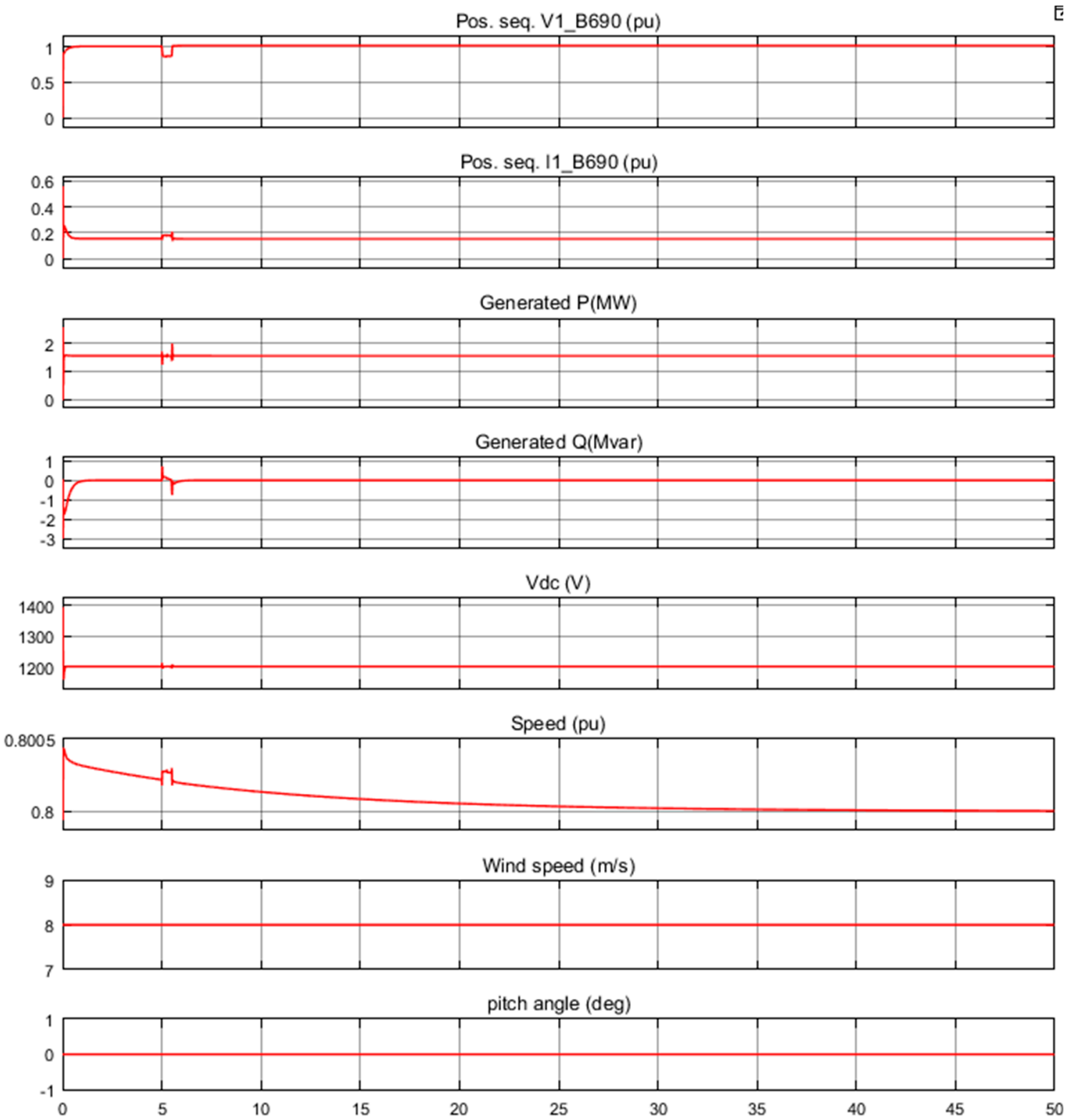

Figure 10. Characteristics of the WPP operation with a voltage drop in the $35 \mathrm{kV}$ system for "AC adjustment" operation mode.

As can be seen in Figures 8 and 9, the last three waveforms represent the voltage, current, and rotational speed of the rotor motor. Figure 10 shows that the wind farm generates $1.55 \mathrm{MW}$ of power. At $t=5 \mathrm{~s}$, the voltage drops below 0.9 units, and at $t=5.22 \mathrm{~s}$, the protection system shuts off the installation, as a reduced voltage of more than $0.2 \mathrm{~s}$ is detected (which is specified in the electric motor protection system). The electric motor current drops to zero and the engine speed gradually decreases, while the wind farm continues to generate energy at 1.55 MW. After the plant is shut down, 1.44 MW of power is exported to the electricity grid.

Next, the operating mode of the wind farm is changed to "Voltage regulation" and the simulation is repeated. The simulation results show that the electric motor is no longer shut off. This is due to the fact that the voltage supplied by the 5 MVar, the reactive power generated by wind turbines during the voltage drop, is sustained and maintains the installation voltage above the protection threshold of 0.9 units. The installation voltage 
during voltage drop is now 0.945 units. The motor response to the voltage drop in the $35 \mathrm{kV}$ system for WPP “Voltage regulation" operation mode is presented in Figure 11, and the voltage of the electric motor for a voltage drop is shown in Figure 12.
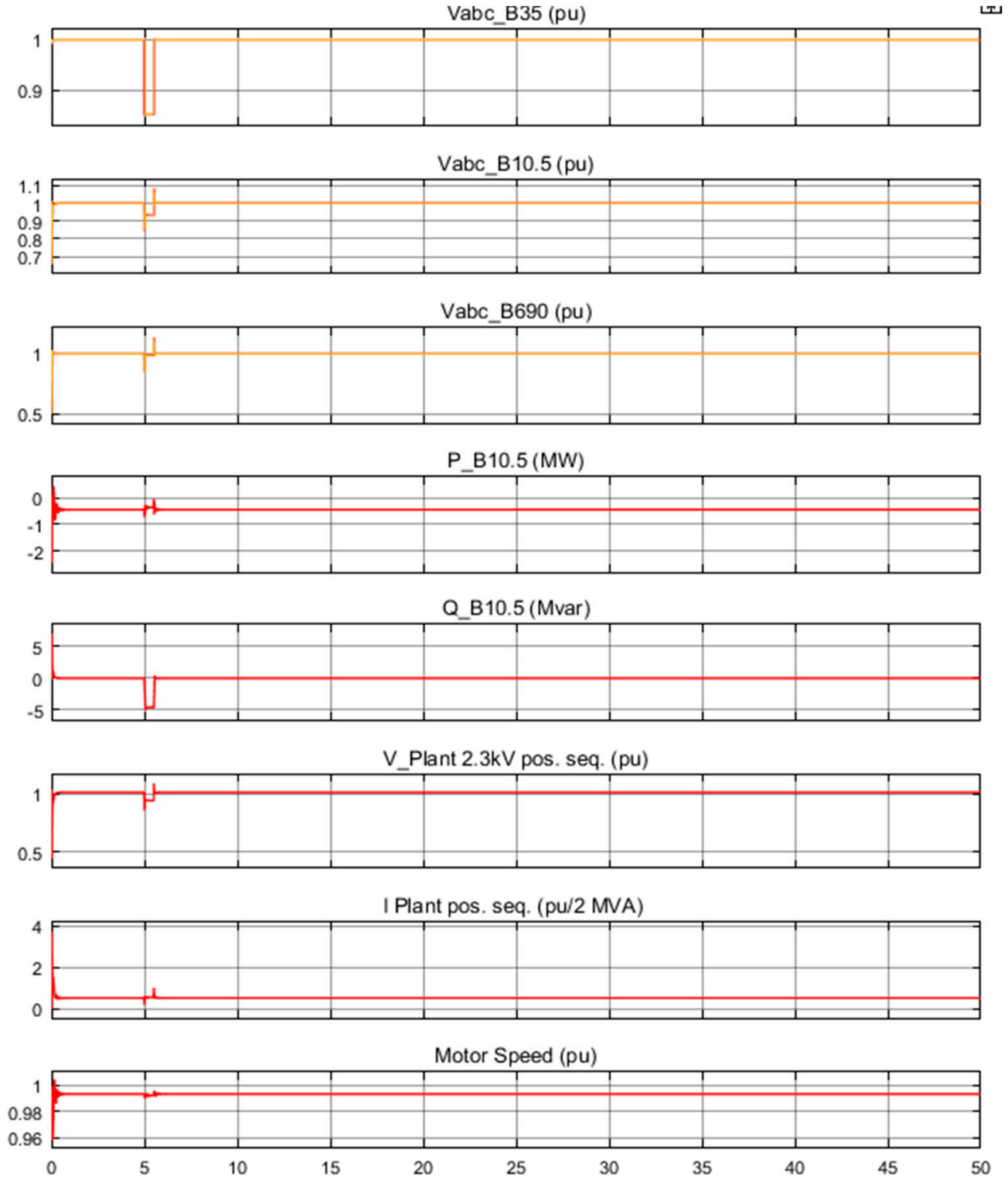

Figure 11. Characteristics of the motor response to voltage drop in the $35 \mathrm{kV}$ system the WPP "Voltage Regulation" operation mode.

V_Plant 2.3kV pos. seq. (pu)

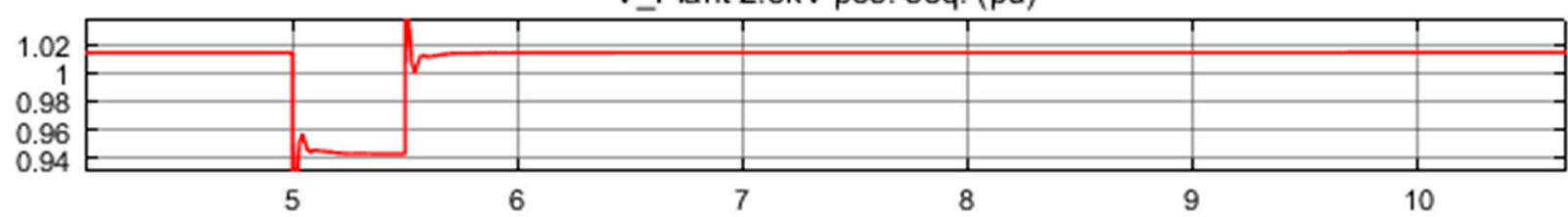

Figure 12. Voltage of electric motor at voltage drop in the $35 \mathrm{kV}$ system at WPP "Voltage regulation" operation mode.

The characteristics of the wind farm operation at a voltage drop in the system of $35 \mathrm{kV}$ "Voltage regulation" mode are shown in Figure 13. 

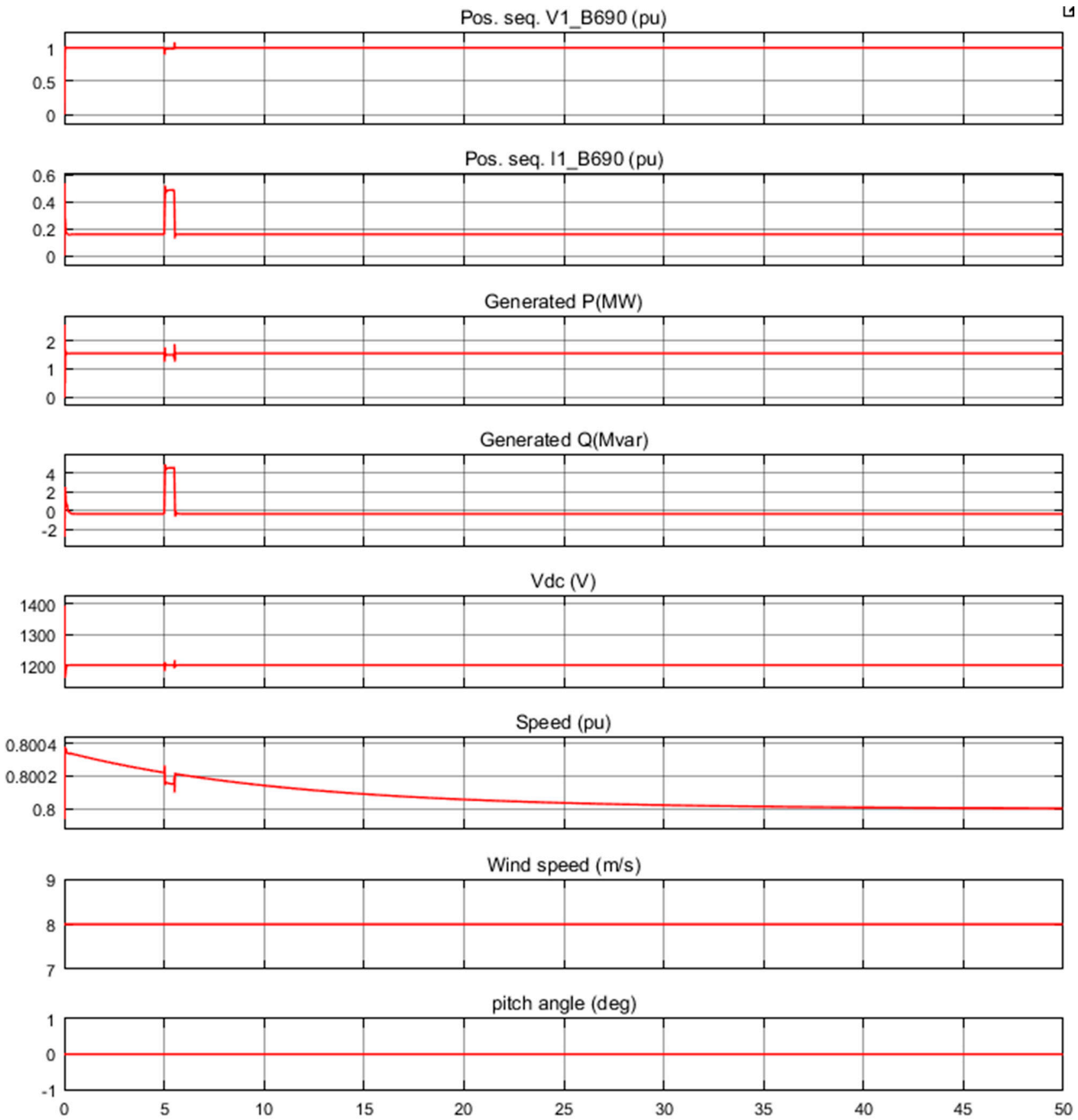

Figure 13. Characteristics of the WPP operation at a voltage drop in the $35 \mathrm{kV}$ system for "Voltage regulation".

\subsection{Simulation of Wind Farm Operation in Conditions of Single-Phase Short Circuit}

We performed a simulation of a single-phase short circuit on earth in a system of $10.5 \mathrm{kV}$. The short circuit was programmed for time $t=5 \mathrm{~s}$, duration $5+9 / 60 \mathrm{~s}$.

At the beginning, the wind speed was set to $8 \mathrm{~m} / \mathrm{s}$; then, at $\mathrm{t}=5 \mathrm{~s}$, the wind speed increased to $14 \mathrm{~m} / \mathrm{s}$.

The first simulation of a single-phase short circuit in a system with a voltage of $10.5 \mathrm{kV}$ was carried out at the operation mode of WPP "Voltage regulation".

The simulation results of a single-phase short circuit to earth in a system of voltage $10.5 \mathrm{kV}$ for "Voltage regulation" operation mode are shown in Figure 14, while the wind farm output voltage value when modeling a single-phase short circuit to the earth in a system of voltage $10.5 \mathrm{kV}$ for "Voltage regulation" operation mode is shown in Figure 15. 

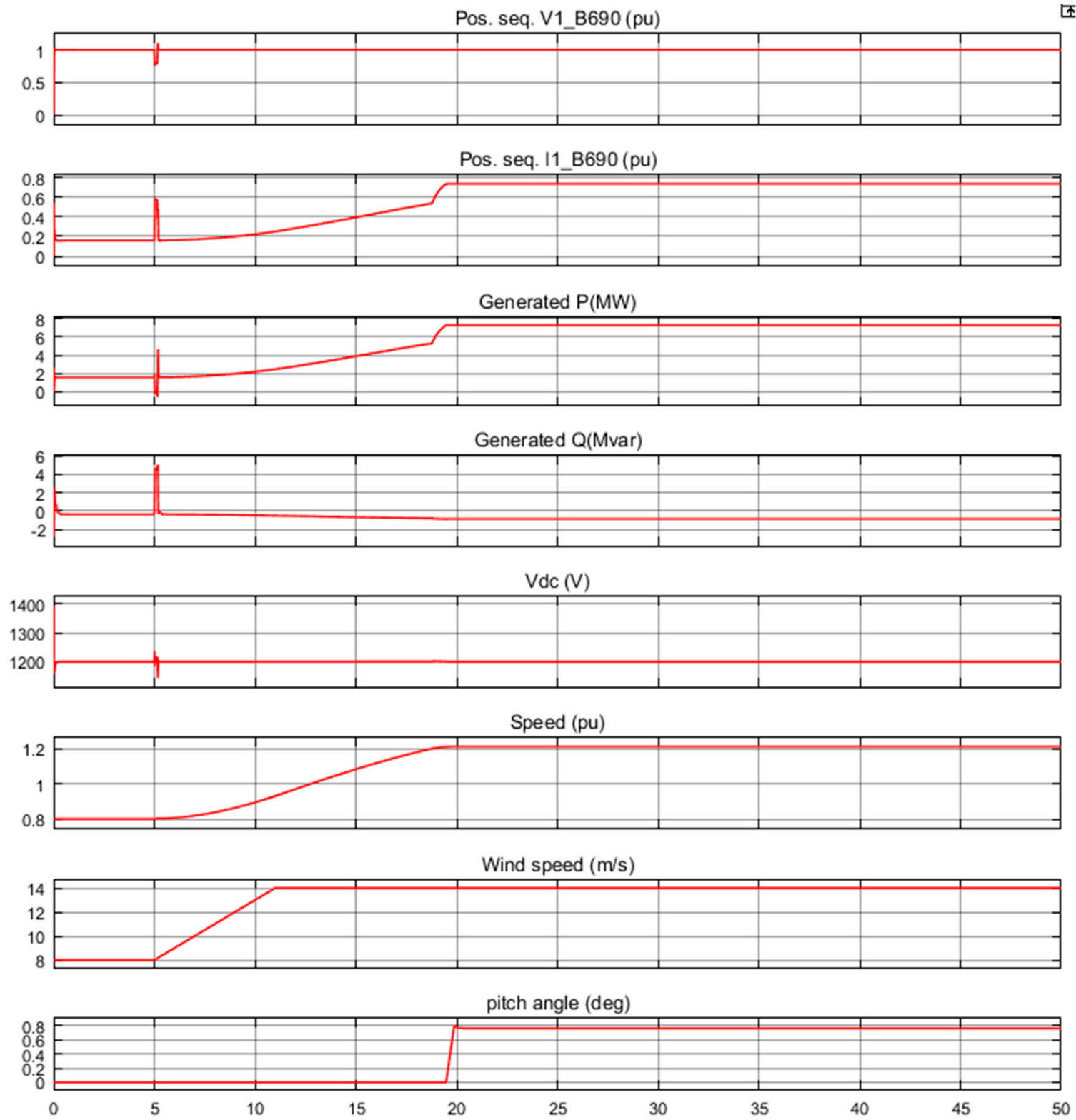

Figure 14. Characteristics the wind farm operation in a simulation of a single-phase short circuit to earth in a system with a voltage of $10.5 \mathrm{kV}$ for "Voltage regulation" operation mode.

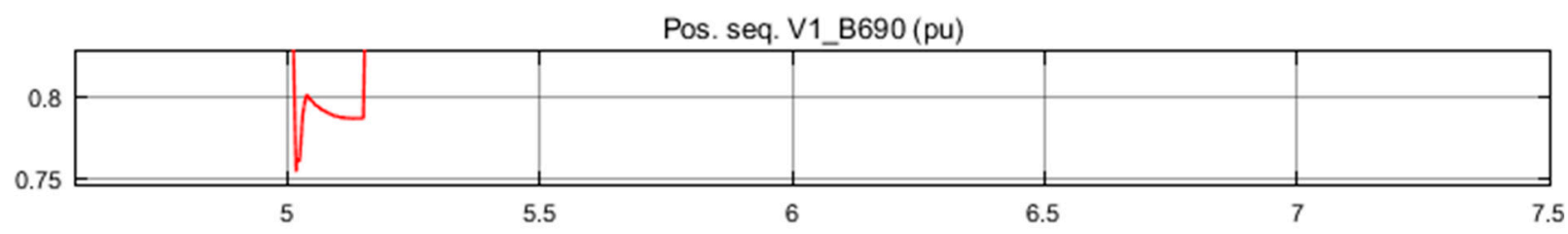

Figure 15. The value of the wind farm output voltage in a simulation of the 1st short circuit to earth in a system with a voltage of $10.5 \mathrm{kV}$ for the "Voltage regulation" operation mode.

\section{Conclusions}

In this article, modelling of operation modes for a wind power plant with an installed capacity of 30 MW was carried out. Twelve Fuhrländer FL 2500/104 wind turbines, with an installed capacity of $2.5 \mathrm{MW}$ each, were selected for the wind farm. This was a wind farm of the variable rotational speed type equipped with an asynchronous doubly fed induction generator. When developing the main scheme of the wind power plant, it was decided to 
use a modular-trunk power distribution scheme. The central substation used: two high voltage switchgears; a $10 \mathrm{kV}$ switchgear connected according to a "One single, sectioned by a circuit breaker, bus system" scheme, and a $35 \mathrm{kV}$ switchgear connected according to a "Bridge with a switch in the transformer circuits and a repair jumper on the power line side" scheme.

For the development of wind power modules, it was proposed to use four modules, each including three wind turbines of $2.5 \mathrm{MW}$, respectively; the capacity of one module was 7.5 MW. Each wind turbine has its own independent transformer, with a natural circulation of oil and air, and with a voltage of $0.69 / 10.5 \mathrm{kV}$. Three voltage classes were used, $690 \mathrm{~V}$, $10.5 \mathrm{kV}$, and $35 \mathrm{kV}$. An active load of $50 \mathrm{~kW}$ is connected to a voltage of $690 \mathrm{~V}$ and an asynchronous motor with a power of $1 \mathrm{MW}$ is connected on the $10.5 \mathrm{kV}$ side.

The aim of this study is to simulate emergency modes, as well as to show graphically the characteristics and transition processes that may arise at a wind farm. The simulation of three operation modes of wind turbines was carried out. The first was "Normal operation" mode. The operation of the wind turbines was set to the "Voltage regulation" mode. In the "Voltage regulation" operating mode, one can see that the wind turbines consume 0.6 MVar of reactive power from the network, thereby maintaining the nominal voltage at a level of $690 \mathrm{~V}$. When the wind turbines operate in the "AC regulation" mode, one can see that the wind turbines already do not consume reactive power from the network, and the nominal voltage deviates by $2 \%$ from the nominal. The second operating mode is "Voltage drop in the $35 \mathrm{kV}$ system". The operation of the wind turbines is set to the "AC regulation" operating mode, and the wind speed is constant and equal to $8 \mathrm{~m} / \mathrm{s}$. As can be seen from the oscillograms-during $5 \mathrm{~s}$ - there is a voltage drop in the $35 \mathrm{kV}$ system, lasting $0.5 \mathrm{~s}$; thus, the voltage on the motor drops by almost 13\%, and since the voltage drop lasts more than $0.2 \mathrm{~s}$, the motor protection is triggered and is turned off. At this time, the wind farm continues to generate $1.5 \mathrm{MW}$ of power into the grid. For the wind turbine operating in "Voltage regulation" mode, the engine is not switched off; at the moment of the voltage drop in the $35 \mathrm{kV}$ system, the wind farm begins to generate reactive power, thereby preventing the voltage drop on the motor to less than $10 \%$. Due to this, the motor remains in operation. At the same time, the wind farm generates $0.5 \mathrm{MW}$ of power into the grid.

The third mode of operation is the simulation of a single-phase short circuit in a $10.5 \mathrm{kV}$ system. For the wind farm in "Voltage regulation" operating mode, a short circuit occurs in the fifth second and the voltage at the terminals of the generators drops by $24 \%$, while the generator shutdown is programmed for a voltage drop of more than $25 \%$ and if the duration exceeds $0.1 \mathrm{~s}$. Thus, due to the generation of reactive power, the wind farm remains in operation. In the case of a similar simulation, but with the wind farm in "AC regulation" operation mode, the wind farm is turned off, as the voltage at the generator terminals drops by $33 \%$ and the duration exceeds $0.1 \mathrm{~s}$.

The simulation results demonstrate in which permissible emergency modes a wind farm can continue to generate energy and in which it should disconnect. From the perspective of power generation, the most unfavorable conditions are sudden voltage drops, which will cause a reduction in power generation, both in AC regulation and Voltage regulation mode. In addition, energy production will be stopped when a short circuit occurs during AC regulation mode.

Author Contributions: Conceptualization, M.Z.Q., O.M., T.S. and R.K.; methodology, M.Z.Q., O.M., T.S., R.K., A.T. and M.Z.; software, M.Z.Q., O.M., T.S. and A.I.; validation, M.Z.Q., O.M., T.S., W.K. and K.D.; formal analysis, A.T., J.F., R.K., A.I., W.K., P.B.-W., M.Z. and K.D.; investigation, M.Z.Q., O.M., T.S., K.D., P.B.-W. and R.K.; resources, M.Z.Q., O.M., T.S., W.K., A.I. and M.Z.; data curation, M.Z.Q., O.M. and T.S.; writing—original draft preparation, M.Z.Q., O.M., T.S., R.K., A.I., W.K., A.T., J.F., P.B.-W., M.Z. and K.D.; writing—review and editing, M.Z.Q., O.M., T.S., R.K., A.I., W.K., A.T., J.F., P.B.-W., M.Z. and K.D.; visualization, M.Z.Q., O.M. and T.S.; supervision, A.T., J.F., R.K., A.I., W.K., P.B.-W., M.Z. and K.D.; funding acquisition, A.I. and M.Z. All authors have read and agreed to the published version of the manuscript.

Funding: The APC was funded by Częstochowa University of Technology. 
Institutional Review Board Statement: Not applicable.

Informed Consent Statement: Not applicable.

Data Availability Statement: The data presented in this study are available on request from the authors.

Conflicts of Interest: The authors declare no conflict of interests.

\section{References}

1. WWEA. Worldwide Wind Capacity Reaches 744 Gigawatts-An Unprecedented 93 Gigawatts Added in 2020. World Wind Energy Assoc. Available online: https:/ / wwindea.org/worldwide-wind-capacity-reaches-744-gigawatts / (accessed on 26 March 2021).

2. Huber, M.; Dimkova, D.; Hamacher, T. Integration of Wind and Solar Power in Europe: Assessment of Flexibility Requirements. Energy 2014, 69, 236-246. [CrossRef]

3. Nadour, M.; Essadki, A.; Nasser, T. Improving low-voltage ride-through capability of a multimegawatt DFIG based wind turbine under grid faults. Prot. Control. Mod. Power Syst. 2020, 5, 33. [CrossRef]

4. Komada, P.; Trunova, I.; Miroshnyk, O.O.; Savchenko, O.A.; Shchur, T.G. The Incentive Scheme for Maintaining or Improving Power Supply Quality. Prz. Elektrotech. 2019, 95, 79-82. [CrossRef]

5. Wang, L.; Wu, J.; Tang, Z.; Wang, T. An Integration Optimization Method for Power Collection Systems of Offshore Wind Farms. Energies 2019, 12, 3965. [CrossRef]

6. Pantsyr, Y.; Garasymchuk, I.; Duganets, V.; Melnyk, M.; Yurchenko, O. Current State and Prospects of Wind Energy Development in Ukraine. E3S Web Conf. 2020, 154, 06004. [CrossRef]

7. Evwind. Ukraine Will Benefit from Wind Energy but Policy Fixes Are Needed for a Quicker Expansion/REVE News of the Wind Sector in Spain and in the World. Available online: https: / /www.evwind.es/2021/04/24/ukraine-will-benefit-from-windenergy-but-policy-fixes-are-needed-for-a-quicker-expansion/80482 (accessed on 5 May 2021).

8. GKD 341.003.001.002-2000. Rules for Designing Wind Power Plants. 2000.

9. González, J.S.; Payán, M.B.; Santos, J.M.R.; González-Longatt, F. A review and recent developments in the optimal wind-turbine micro-siting problem. Renew. Sustain. Energy Rev. 2014, 30, 133-144. [CrossRef]

10. Miroshnyk, O.; Lukasik, Z.; Szafraniec, A.; Lezhniuk, P.; Kovalyshyn, S.; Shchur, T. Reducing the Dissymmetry of Load Currents in Electrical Networks 0,4/0,23 KV Using Artificial Neural Networks. Prz. Elektrotech. 2019, 1, 247-251. [CrossRef]

11. Quinonez-Varela, G.; Ault, G.W.; Anaya-Lara, O.; McDonald, J.R. Electrical collector system options for large offshore wind farms. IET Renew. Power Gener. 2007, 1, 107-114. [CrossRef]

12. Trunova, I.; Miroshnik, O.; Savchenko, O.; Moroz, O.; Pazyi, V.; Shchur, T.; Kasner, R.; Bałdowska-Witos, P. Scheduling of Preventive Maintenance of an Power Equipment of the Agricultural Enterprises. J. Phys. Conf. Ser. 2021, 1781, 012018. [CrossRef]

13. Al_Issa, H.A.; Qawaqzeh, M.; Khasawneh, A.; Buinyi, R.; Bezruchko, V.; Miroshnyk, O. Correct Cross-Section of Cable Screen in a Medium Voltage Collector Network with Isolated Neutral of a Wind Power Plant. Energies 2021, 14, 3026. [CrossRef]

14. Savchenko, O.A.; Miroshnyk, O.O.; Dubko, S.V.; Shchur, T.G.; Komada, P.; Mussabekov, K. Justification of Ice Melting Capacity on 6-10 kV OPL Distributing Power Networks Based on Fuzzy Modeling. Prz. Elektrotech. 2019, 95, 106-109. [CrossRef]

15. Bałdowska-Witos, P.; Kruszelnicka, W.; Kasner, R.; Tomporowski, A.; Flizikowski, J.; Kłos, Z.; Piotrowska, K.; Markowska, K. Application of LCA Method for Assessment of Environmental Impacts of a Polylactide (PLA) Bottle Shaping. Polymers 2020, 12, 388. [CrossRef]

16. Canbulat, S.; Balci, K.; Canbulat, O.; Bayram, I.S. Techno-Economic Analysis of On-Site Energy Storage Units to Mitigate Wind Energy Curtailment: A Case Study in Scotland. Energies 2021, 14, 1691. [CrossRef]

17. Silva, J.E.; Danao, L.A.M. Varying VAWT Cluster Configuration and the Effect on Individual Rotor and Overall Cluster Performance. Energies 2021, 14, 1567. [CrossRef]

18. Ju, X.; Liu, F. Wind farm layout optimization using self-informed genetic algorithm with information guided exploitation. Appl. Energy 2019, 248, 429-445. [CrossRef]

19. Liu, F.; Ju, X.; Wang, N.; Wangg, L.; Leeh, W.-J. Wind farm macro-siting optimization with insightful bi-criteria identification and relocation mechanism in genetic algorithm. Energy Convers. Manag. 2020, 217, 112964. [CrossRef]

20. Ju, X.; Liu, F.; Wang, L.; Lee, W.-J. Wind farm layout optimization based on support vector regression guided genetic algorithm with consideration of participation among landowners. Energy Convers. Manag. 2019, 196, 1267-1281. [CrossRef]

21. Kasner, R.; Kruszelnicka, W.; Bałdowska-Witos, P.; Flizikowski, J.; Tomporowski, A. Sustainable Wind Power Plant Modernization. Energies 2020, 13, 1461. [CrossRef]

22. Fantauzzi, M.; Lauria, D.; Mottola, F.; Proto, D. Estimating Wind Farm Transformers Rating through Lifetime Characterization Based on Stochastic Modeling of Wind Power. Energies 2021, 14, 1498. [CrossRef]

23. González, J.S.; Rodríguez, A.G.G.; Mora, J.C.; Payána, M.B.; Santosa, J.R. Overall design optimization of wind farms. Renew. Energy 2011, 36, 1973-1982. [CrossRef]

24. Modukpe, G.; Diei, D. Modeling and Simulation of a $10 \mathrm{KW}$ Wind Energy in the Coastal Area of Southern Nigeria: Case of Ogoja; IntechOpen: London, UK, 2020; ISBN 978-1-78984-591-4.

25. Cuesta, A.B.; Gomez-Gil, F.J.; Fraile, J.V.M.; Rodríguez, J.A.; Calvo, J.R.; Vara, J.P. Feasibility of a Simple Small Wind Turbine with Variable-Speed Regulation Made of Commercial Components. Energies 2013, 6, 3373-3391. [CrossRef] 
26. Baloch, M.; Campus, K.; Wattoo, A.; Kumar, D.; Kaloi, G.; Pakistan, S.; Memon, A.; Tahir, S.; Wattoo, W.A. Active and Reactive Power Control of a Variable Speed Wind Energy Conversion System Based on Cage Generator. Int. J. Adv. Comput. Sci. Appl. 2017, 8, 197-202. [CrossRef]

27. Saheb-Koussa, D.; Haddadi, M.; Belhamel, M.; koussa, M.; noureddine, S. Modeling and Simulation of Windgenerator with Fixed Speed Wind Turbine under Matlab-Simulink. Energy Procedia 2012, 18, 701-708. [CrossRef]

28. Nawaz, A. Simulation of Variable Speed Wind Turbine Voltage Regulation Model Using MATLAB/Simulink. Int. J. Eng. Adv. Technol. 2013, 2, 357-360.

29. Jansuya, P.; Kumsuwan, Y. Design of MATLAB/Simulink Modeling of Fixed-Pitch Angle Wind Turbine Simulator. Energy Procedia 2013, 34, 362-370. [CrossRef]

30. Qian, M.; Zhao, D.; Jiang, D.; Zhu, L.; Ma, J. Active and Reactive Power Control of Wind Farm Based on Integrated Platform of PowerFactory and MATLAB. In PowerFactory Applications for Power System Analysis; Gonzalez-Longatt, F.M., Luis Rueda, J., Eds.; Power Systems; Springer International Publishing: Cham, Switzerland, 2014; pp. 421-446. ISBN 978-3-319-12958-7.

31. Mohammadpour, H.A.; Ghaderi, A.; Santi, E. Analysis of Sub-Synchronous Resonance in Doubly-Fed Induction Generator-Based Wind Farms Interfaced with Gate-Controlled Series Capacitor. IET Gener. Transm. Distrib. 2014, 8, 1998-2011. [CrossRef]

32. Eriksson, S. Direct Driven Generators for Vertical Axis Wind Turbines; Acta Universitatis Uppsaliensis: Uppsala, Sweden, 2008.

33. Bykov, E. Justification of the Parameters of a Wind Power Installation with Spiral Blades Based on Experimental Studies. Ph.D. Thesis, St. Petersburg State Polytechnical University, St. Petersburg, Russia, 2007.

34. Klimina, L.A. The Vertical-Axis Wind Turbine: Dynamics and Control. Ph.D. Thesis, Moscow State University M.V. Lomonosova, Moscow, Russia, 2010.

35. Belei, V.F.; Nikishin, A.Y. Calculation of electricity generation by wind power plants according to wind potential. In Electrical Equipment of Ships and Electric Power Industry: Collection. Scientific tr; Publishing House of KSTU: Kaliningrad, Russia, 2004; pp. 4-6.

36. Burykin, O. Optimization of the Functioning of the Renewable Energy Sources in the Local Electrical Systems. Prz. Elektrotech. 2017, 1, 99-104. [CrossRef]

37. Gils, H.C.; Scholz, Y.; Pregger, T.; Luca de Tena, D.; Heide, D. Integrated Modelling of Variable Renewable Energy-Based Power Supply in Europe. Energy 2017, 123, 173-188. [CrossRef]

38. Fuhrländer FL 2500/104-2, 50 MW—Wind Turbine. Available online: https:/ / en.wind-turbine-models.com/turbines/1346 -fuhrlaender-fl-2500-104 (accessed on 27 May 2021). 